\title{
PENGEMBANGAN MATERI AJAR BAHASA ARAB TERPADU BERBASIS TEMA DI MTS THAWALIB PADANG PANJANG
}

\author{
M. Yusuf Salam \\ Institut Agama Islam Negeri Batusangkar \\ e-mail: yusufsalam@iainbatusangkar.ac.id
}

\begin{abstract}
Abstrak: Tujuan penelitian ini adalah mendeskripsikan (1) desain bahan ajar bahasa Arab Terpadu berbasis tema di kelas VII MTs Thawalib Padang Panjang, (2) kelayakan bahan ajar bahasa Arab terpadu berbasis tema, dan (3) efektifitas penggunaan bahan ajar bahasa Arab terpadu berbasis tema dalam pembelajaran. Penelitian ini menggunakan rancangan penelitian pengembangan. Model pengembangan yang digunakan pada penelitian ini mengacu pada model pengembangan Research and Development (R\&D) Borg and Gall yang disederhanakan menjadi beberapa langkah, yaitu (1) analisis potensi dan masalah, (2) mendesain produk, (3) mengumpulkan materi, (4) membuat produk awal, (5) melakukan uji ahli, (6) merevisi produk, dan (7) melakukan uji lapangan. Data dalam penelitian ini berupa data kuantitatif dan kualitatif. Data kuantitatif diperoleh dari hasil angket untuk ahli media, ahli materi, dan subjek penelitian. Instrumen yang digunakan dalam pengumpulan data pengembangan bahan ajar pembelajaran ini adalah instrumen berbentuk angket terstruktur dan penilaiannya menggunakan skala bertingkat. Sedangkan untuk mendapatkan data kualitatif pada tahap uji lapangan peneliti menggunakan metode observasi. Penelitian ini menghasilkan sebuah produk materi ajar bahasa Arab terpadu berbasis tema yang dikategorikan layak berdasarkan uji lapangan.
\end{abstract}

Kata Kunci: materi, bahasa Arab, terpadu, tema.

Abstract: This study aims at describing (1) the design of theme-based integrated Arabic instructional materials for VII grade of Thawalib Padang Panjang Islamic Boarding School, (2) the validity of themebased integrated Arabic instructional materials, and (3) the effectiveness of the use of theme-based integrated Arabic instructional materials in teaching and learning process. The type of this research is research and development (R and D). The development model used is based on Borg and Gall model which was modified by Sugiyono by applying the following steps: (1) analyzing potential and problems, (2) collecting data, (3) designing prototype, (4) validating the prototype, (5) prototype trial, (6) revising prototype, (7) product trial, (8) revising the prototype, (9) revising product, and (10) mass production. The data used are quantitative and qualitative data. Quantitative data were obtained from the result of questionnaire given to two experts: media and materials experts, and the respondents of the research. The instrument used was rating scale structured closed-questionnaire. Whereas, qualitative data were obtained by doing field observation. The result of this research is a valid and worthy product of theme-based integrated Arabic instructional materials.

Keywords: Instructional, Arabic Language, Integrated, Theme

\section{PENDAHULUAN}

Penerapan sistem pembelajaran bahasa Arab di Indonesia pada awal tiga puluhan abad ke-
20 telah berlangsung dengan dua sistem; terpadu dan separasi. Sistem tersebut berlangsung pelaksanaannya dalam pembelajaran bahasa dengan orientasi yang 
berbeda. Sistem terpadu menunjukan satu kesatuan yang tak dapat dipisah-pisahkan antara unsur-unsur fungsional dari bahasa. Sedangkan sistem separasi diterapkan dalam pembelajaran bahasa secara terpisah yang memisahkan empat kemampuan berbahasa dan ilmu bahasa (Salam, 2011: 104).

Sistem terpadu yang menjadi fokus pembahasan penulis yang berkembang di Indonesia diawali dari sejarah kegagalan sistem separasi. Zulhannam (2014: 86) mengungkapkan bahwa pengikut aliran sistem terpadu mengkritik sistem separasi di sisi sudut pandang filsafat bahasa, baik dari segi penerapan, pembelajaran, maupun fungsinya. Mereka menganggap kekurangan terbesar sparated system adalah pengajaran bahasa yang dilakukan secara terpisah-pisah antara kemampuan berbahasa satu dengan yang lainnya. Bahasa tidak ditempatkan pada posisi yang sebenarnya, yaitu satu kesatuan yang utuh.

Menurut Hasan Za'far al-Khalifah (2004: 84), bahwa otak manusia dalam teori psikologi lebih dahulu mendeteksi keseluruhan sebelum mendeteksi bagianbagian. Dalam proses belajar bahasa, otak peserta didik lebih mudah menguasai keempat kompetensi bahasa Arab secara bersamaan dalam satu kesempatan pembelajaran dibanding dengan sistem terpisah. Biasanya pembelajaran bahasa Arab secara terpisah bagi peserta didik berujung kesulitan dalam mengubungan satu sama lainnya. Ta'bir, istima', qiroah, kitabah, nabwu dan shorof diajarkan secara terpisah misalnya, ketika peserta didik diperintah untuk menerapkan membaca atau menulis dan menyusun kata sesuai kaidah nahwu dan shorof akan mengalami kebingungan dan kesulitan.

Melihat kenyataan tersebut timbul gagasan oleh pembaharu pengajaran bahasa Arab di Indonesia untuk menggunakan sistem terpadu dalam pengajaran bahasa Arab. Usaha ini sebagai tahap pertama tahun tigapuluhan pada awal abad 20. Skala yang lebih luas diiringgi oleh Depertemen Agama pada awal tujuhpuluhan. Dengan menganut sistem tersebut, bahan ajar sebagai instrumen utamanya didesain dalam berbagai bentuk; bahan ajar bahasa Arab terpadu berbasis tema atau teks bacaan, dan pembelajaran berbasis situasi atau teks percakapan.

Belakangan ini pembelajaran bahasa Arab terpadu telah banyak dikaji. Di antaranya Imam Ma'ruf mambahas pada aspek manajemennya (2016: 278). Hasil penelitiannya menunjukkan bahwa pola integrasi pembelajaran bahasa Arab di MA Al-Mukmin terbukti mampu menghasilkan lulusan yang terampil berbahasa Arab aktif secara lisan dan tulisan. Kajian ini dikuatkan oleh Widi Astuti (2015: 127) tentang pelaksanaan pembelajaran terpadu di MAPK MAN 1 Surakarta telah membentuk siswa berkelompok dan menciptakan suasana bahasa Arab yang hidup dan bermakna di luar kelas formal. Pandangan ini juga dikuatkan oleh Supardi (2018: 26) tentang model pembelajaran terpadu di perguruan tinggi menjadikan pembelajar akan termotivasi aktif dalam proses belajar sehingga mereka memperoleh keterampilan berbahasa secara utuh dan dapat menggunakan bahasa secara komunikatif.

Beberapa kajian di atas lebih menekankan pada manajemen dan model pembelajaran bahasa Arab terpadu. Namun, salah satu komponen penting dalam pembelajaran bahasa Arab terpadu adalah bahan ajar. Kajian ini masih sangat jarang ditemukan. Padahal proses pembelajaran tidak terlepas dari penggunaan bahan ajar. Bahan ajar mempunyai peranan penting dalam pencapaian kompetensi yang harus dicapai oleh siswa. Tujuan dari penulisan artikel ini agar guru mengetahui pentingnya pengembangan bahan ajar terpadu untuk mencapai pembelajaran yang bermakna bagi siswa MTs. Sehingga diharapkan sebelum melaksanakan pembelajaran, guru mempersiapkan bahan ajar yang sesuai dengan kebutuhan dan tingkat perkembangan siswa agar diperoleh kebermaknaan dalam belajar. 
Barangkali karena alasan itulah penulis memfokuskan pada pada pengembangan materi ajar di Thawalib Padang Panjang. Pondok Pesantren ini merupakan lembaga pendidikan Islam tertua di sumatera Barat yang berdiri tanggal 15 Januari 1919. Perkembangan kurikulum lokal Thawalib Padang Panjang masih menerapkan sistem terpisah-pisah pada setiap tingkat. Implikasi proses tersebut menunjukkan bahwa $80 \%$ siswa pemula di perguruan Thawalib Padang Panjang mengalami kesulitan dalam berbahasa Arab.

Berdasarkan masalah diungkapkan di atas, maka perlu adanya upaya untuk menyelesaikan problema tersebut. Problematika ini menurut hemat penulis bersumber ketidaktersediaan materi ajar yang memungkinkan siswa memahami ilmuilmu kebahasaaraban melalui satu teks. Buku-buku mengenai bahasa Arab sudah banyak disusun oleh para ahli, tetapi pada umumnya menggunakan pendekatan normatif-konvensional, menekankan pada nama nama mata pelajaran yang terpisah, sehingga tidak semua siswa mampu menyerap dan memahaminya dengan baik.

Dalam hal ini penulis menfokuskan pengembangan bahan ajar terpadu di Perguruan Thawalib padang Panjang berbasis tema atau teks bacaan yang kemudian dikembangkan berbagai kegiatan pembelajaran. Tema sentral dalam tulisan ini diambil dari teori yang dikembangkan Mahmud Yunus (1983: 26) yang dituangkan dalam bacaan (al-muthalaah), percakapan, nahu/sharaf dan sebagainya. Buku Durûs AlLughah Al-'Arabiyyah karya Mahmud Yunus (1927) merupakan contoh bahan ajar berbasis Nazariyyah Al-Wibdah. Bentuk variasi bahan utama buku tersebut berfokus kepada materi bacaan yang dikembangkan dalam bentuk kosakata, percakapan, struktur kalimat, dan menulis. Fokus utama dapat dilakukan dengan mengaitkannya dengan pembelajaran yang setelahnya secara terpadu dan saling koordinatif antar materi.

Berangkat dari kondisi riil tersebut, penulis terdorong untuk mengungkapan cuplikan hasil penelitian dengan judul: Pengembangan Bahan Ajar Bahasa Arab Terpadu berbasis Tema di MTs Thawalib Padang Panjang.

\section{METODE}

Penelitian ini didesain dengan penelitian dan pengembangan $(\mathrm{R} \& \mathrm{D})$ karena penelitian ini menghasilkan sebuah produk bahan ajar bahasa Arab terpadu yang sebelumnya belum ada, dengan kata lain hasil bahan ajar pada penelitian ini merupakan hasil pengembangan karena menghasilkan sebuah produk baru.

Jenis data penelitian ini adalah data kualitatif dan kuantitatif. Data dianalisis secara statistik deskriptif. Data kualitatif dilakukan melalui wawancara dan pengamatan kelas untuk mendapatkan deskripsi atau gambaran dari objek yang diteliti. Sedangkan data kuantitatif merupakan hasil dari angket-angket dari ahli materi, ahli media dan subjek penelitian.

Instrumen yang digunakan dalam pengumpulan data pengembangan media pembelajaran ini adalah instrumen berbentuk angket terstruktur, yaitu angket semua pertanyaan yang telah ditentukan jawabannya (Heriyanto, 2006:149). Angket adalah sejumlah pertanyaan tertulis yang digunakan untuk memperoleh informasi dari responden (Arikuntoro dalam Ainin, 2010:107).

Untuk mengembangkan suatu bahan ajar diperlukan persiapan dan rancangan yang diteliti. Dalam pengembangan ini model yang akan dikembangkan adalah mengacu pada model pengembangan Research and Development (R\&D) Borg and Gall yang telah dimodifikasi Sugiyono (2011: 298) yang terdiri dari langkah-langkah berikut: (1) potensi dan masalah, (2) pengumpulan data, (3) desain produk, (4) validasi desain, (5) revisi desain, (6) uji coba produk, (7) revisi produk, (8) uji coba pemakaian, (9) revisi 
produk, dan (10) produksi massal. Untuk menyingkat waktu penelitian, maka peneliti menyederhanakan model Research and Development dari Sugiyono menjadi beberapa langkah sebagai berikut: (1) analisis potensi dan masalah, (2) mendesain produk, (3) mengumpulkan materi, (4) membuat produk awal, (5) melakukan uji ahli, (6) merevisi produk, dan (7) melakukan uji lapangan.

\section{HASIL DAN PEMBAHASAN}

\section{Desain Bahan Ajar Bahasa Arab Terpadu Berbasis Tema}

Studi pendahuluan (pra survey) dilakukan untuk memperoleh data awal yang dapat digunakan sebagai bahan untuk membuat rancangan model dan pengembangannya. Kegiatan pra survey lapangan dilakukan untuk memperoleh data lapangan sebagai bahan empiris yang digunakan dalam penyusunan rancangan model beserta pelaksanaannya. Kegiatan yang dilakukan pada pra survai lapangan ini adalah menghimpun dan menganalisis kondisi lapangan. Kegiatan ini digunakan sebagai bahan dalam merancang model bahan ajar dan pelaksanaan uji coba pengembangan bahan ajar. Kondisi yang dikaji dan dianalisis pada kegiatan ini meliputi: 1) karakteristik siswa sebagai sampel penelitian, 2) karakteristik materi bahan ajar bahasa Arab, dan 3) penyusunan bentuk awal bahan ajar bahasa Arab.

1. Karakteristik Siswa sebagai Sampel Penelitian

Tujuan peneliti mempelajari karakteristik siswa untuk mengetahui kemampuan umum siswa tentang bahasa Arab. Dari hasil kemampuan tersebut dapat ditentukan subjek uji coba penggunaan bahan ajar dan acuan dalam mengembangkan alat tes/tingkat kesulitan soal. Pada tahap ini, peneliti melakukan proses wawancara/interviu dengan guru-guru bahasa Arab dan melakukan analisis dokumen. Dokumen yang dimaksud yaitu daftar hasil studi siswa khususnya beberapa daftar nilai mata pelajaran bahasa Arab siswa calon subjek uji coba yaitu siswa kelas VII. Sebagai hasil mempelajari karakteristik siswa, peneliti menetapkan 5 orang subjek uji coba kelompok kecil dan 28 orang siswa sebagai subjek uji coba lapangan terbatas dengan distribusi terdiri dari 20 orang $(44,44 \%)$ dari kelompok kemampuan rendah, 4 orang $(8,88 \%)$ dari kelompok kemampuan sedang dan 4 orang $(8,88 \%)$ dari kelompok berkemampuan tinggi.

2. Karakteristik Materi Bahan Ajar Bahasa Arab

Materi yang dikembangkan dalam bahan ajar merupakan hasil analisis acuan materi uji bahasa Arab. Materi bersumber dari kurikulum lokal Pondok Pesantren Thawalib Padang Panjang. Prinsip yang diacu dalam menetapkan bahan ajar bahasa Arab berdasarkan uji kemampuan dasar bahasa Arab. Peneliti benar-benar berusaha memilih materi bahasa Arab yang merupakan dasar atau fundamental dari materi bahasa Arab secara keseluruhan.

Berdasarkan hasil acuan materi bahan ajar bahasa Arab dan mengacu pada prinsip yang diuraikan di atas, maka peneliti menetapkan materi bahan ajar bahasa Arab yang akan dikembangkan. Tema materi bahan ajar bahasa Arab yang dimaksud adalah :

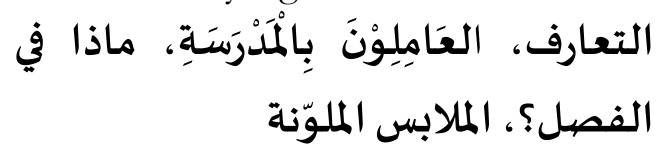

Dari masing-masing pokok dan sub pokok materi setiap bahan ajar diuraikan pada tabel berikut: 


\begin{tabular}{|c|c|c|c|c|}
\hline Bahan ajar & Tema & $\begin{array}{c}\text { Kegiatan } \\
\text { Belajar }\end{array}$ & Pokok Bahasan & Sub Pokol Bahasan \\
\hline \multirow[t]{2}{*}{1} & \multirow[t]{2}{*}{ النعارف } & \multirow[t]{2}{*}{1} & Nuhadasah & 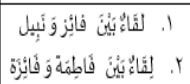 \\
\hline & & & Muthalaah & 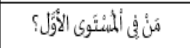 \\
\hline \multirow{2}{*}{2} & \multirow{2}{*}{ 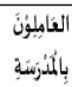 } & 1 & Muhadasah & 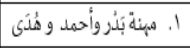 \\
\hline & & 2 & Nuthalaah & 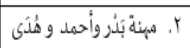 \\
\hline \multirow{3}{*}{3} & \multirow[b]{2}{*}{ الفصل؛ ماذِ } & 1 & Muhadasah & 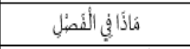 \\
\hline & & 2 & Nuthalaah & 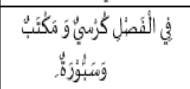 \\
\hline & & & Kitabah & كتابة حرف" الثاء والنون \\
\hline \multirow{3}{*}{4} & \multirow{3}{*}{ الملمولة ابس } & 1 & Nuhadasah & 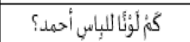 \\
\hline & & & Muthalaah & 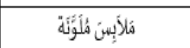 \\
\hline & & & \begin{tabular}{|l} 
Kitabah huruf \\
\end{tabular} & كتابة حرف الكاف والياء \\
\hline
\end{tabular}

3. Penyusunan Bentuk Awal Bahan Ajar Bahasa Arab

Penyusunan awal bahan ajar pembelajaran terpadu ini memodifikasi silabus yang dijadikan acuan dalam pembelajaran bahasa Arab. Hal ini dilakukan karena silabus yang berlaku selama ini disusun secara terpisah-pisah sesuai dengan ilmu bahasa yang diajarkan. Setelah melakukan kajian teoritis dan observasi lapangan, disusun bentuk awal bahan ajar bahasa Arab terpadu yang meliputi: tujuan yang ingin dicapai, materi/wacana, dan evaluasi. Sebelum bahan ajar diujicobakan diadakan beberapa kali diskusi dengan ahli materi dan ahli media. Proses akhir diskusi ditemukan bentuk awal bahan ajar yang dianggap layak untuk diujicobakan di kelas.

Berdasarkan hasil kajian di atas, diperoleh bentuk awal model pembelajaran terpadu, yang meliputi wacana/materi, kemahiran berbahasa dan ilmu bahasa yang dipadukan, tujuan yang ingin dicapai, strategi pengajaran, media pengajaran dan evaluasi. Bentuk awal bahan ajar pembelajaran terpadu meliputi gambaran berikut:

a. Identitas materi/ kerangka: Berisi pokok dan sub pokok bahasan yang dibahas dalam bahan ajar. Kerangka materi dituliskan halaman pertama sebagai gambaran materi yang akan dibahas dalam bahan ajar. Huruf yang digunakan dalam menulis bahan ajar dengan font Sakkal Majalla. Ukuran masing huruf, 18 untuk judul, 16 untuk pokok bahasan dan 12 untuk lainnya. Setiap huruf ditulis dengan warna hitam untuk judul dan lainnya.

b. Pendahuluan: Penulisan pendahuluan bertujuan memberikan ringkasan secara umum kepada siswa tentang materi yang akan dibahas dalam bahan ajar. Selain itu juga dijelaskan tentang kerangka isi materi, hubungan materi/bahan ajar ini dengan materi/bahan ajar berikutnya. Penulisan pendahuluan adalah ditulis dengan huruf times new roman ukuran 12 , hitam tebal, dalam kotak bershadding. Contoh penulisan judul pendahuluan :

\section{PENDAHULUAN}

c. Petunjuk Pembelajaran: penulisan petunjuk pembelajaran pada bahan ajar bertujuan untuk memberikan kemudahan kepada siswa untuk mempelajari bahan ajar. Petunjuk diletakkan diawal bahan ajar sebagai pendahuluan dan menjadi petunjuk pembelajaran bagi keseluruhan penggunaan bahan ajar. Pada akhir tiaptiap uraian isi di setiap kegiatan belajar disajikan lagi petunjuk pembelajaran dengan menggunakan ungkapan direktif untuk memperdalam pemahaman . Contoh petunjuk pembelajaran:

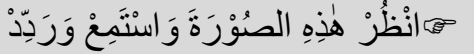

d. Uraian Isi Pembelajaran: Uraian isi pembelajaran yang terdapat pada setiap bahan ajar/kegiatan belajar dimaksudkan untuk memberikan penjelasan yang lengkap tentang sesuatu yang harus diketahui oleh siswa. Uraian isi pembelajaran dilengkapi dengan gambar berwarna dan contoh yang dapat membantu memperjelas uraian materi. Teks percakapan dan bacaan menggunakan ukuran huruf 16 point huruf Sakkal Majalla. Pada tiap bagian penting ditampilkan kotak bershadding kecil warna hitam ringan berisi ungkapan singkat utama/ rumus penting. Judul pokok bahasan ditulis dengan warna 
hitam, serta nomor halaman diletakkan di kiri atas. Bahasa, istilah dan ilustrasi gambar dibuat sesuai dengan karakteristik siswa MTs Thawalib Putra Padang Panjang. Berikut salah satu uraian penting yang dikutip dari salah satu bahan ajar.

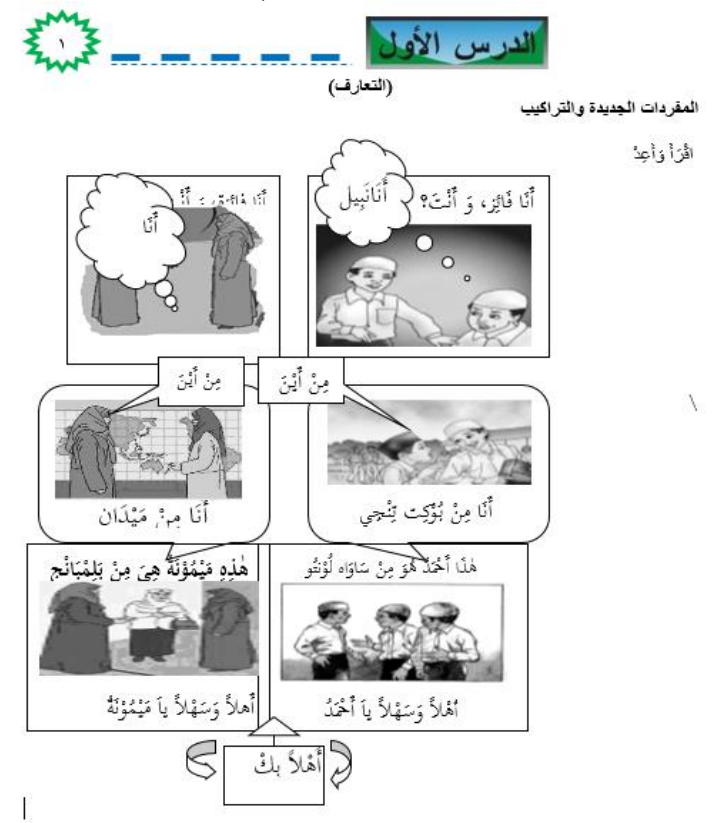

e. Sumber Bacaan: Sumber bacaan yang ditulis pada lembaran akhir bahan ajar ini bertujuan untuk memudahkan siswa mencari dan menelusuri guna memperdalam dan mengembangkan materi yang terdapat dalam bahan ajar. Judul sumber bacaan diawali dengan Sakkal Majalla, bold, 16 point. Teks bahan bacaan ditulis menggunakan ukuran 16 point Sakkal Majalla. Baris kedua ditulis menjorok ke dalam (ke kiri) 7 karakter. Warna huruf yang digunakan hitam.

f. Latihan: Setiap kegiatan belajar dalam bahan ajar ini disusun alat pengukur atau tes berupa soal latihan dengan tujuan untuk mengukur sejauh mana siswa telah mencapai tujuan pembelajaran yang telah ditetapkan. Soal ditulis menggunakan huruf ukuran 16 point Sakkal Majalla diketik dengan spasi 1,5. Latihan ditulis dengan tingkat kesulitan bervariasi dari tingkat kesulitan rendah, sedang dan tinggi. Pada tiap latihan diberikan petunjuk pengerjaan latihan dan diakhir kunci jawaban diberikan petunjuk mengevaluasi hasil belajar untuk mengukur sejauh mana tingkat penguasaan siswa terhadap materi bahan ajar dan sebagai patokan/acuan sebelum melanjutkan ke bahan ajar berikutnya.

Perangkat pembelajaran bahan ajar bahasa Arab yang telah dirancang, selanjutnya dikonsultasikan kepada pakar rancangan dan isi serta pembimbing. Setelah itu rancangan direvisi menurut saran pakar dan pembimbing. Kemudian rancangan tersebut menjadi prototipe awal.

\section{Kelayakan Bahan Ajar Bahasa Arab Terpadu Berbasis Tema}

Bahan ajar pembelajaran bahasa Arab Terpadu telah divalidasi oleh dua pakar materi dan media pendidikan bahasa Arab. Hasil validasi oleh pakar menunjukkan bahwa ada beberapa revisi yang perlu dilakukan terhadap perangkap bahan ajar. Revisi yang perlu dilakukan diantaranya pada: 1) lembar daftar isi belum ada, jika dilengkapi akan lebih memudahkan siswa, 2) belum ada daftar tema, 3) harus ada penyeragaman gambar yang ada dalam buku ini dari sisi warna dan beberapa ukuran(ada beberapa ukuran gambar yang kecil dan kurang jelas, dan 4) perlu penambahan topik yang aplikatif.

Berdasarkan pada kondisi di atas, penulis melakukan revisi bahan ajar bahasa Arab terpadu pada standar kompetensi dasar, yaitu "Siswa mampu memahami bahasa Arab integratif secara Aplikatif" dapat terwujud. Berdasarkan revisi ini, maka secara umum dapat disimpulkan bahwa prototipe perangkat bahan ajar pembelajaran bahasa Arab integratif memenuhi kriteria valid dari segi isi (content validity) dan konstruksi (construct validity). Prototipe perangkat perangkat bahan ajar 
pembelajaran bahasa Arab integratif selanjutnya diujicobakan di kelas VII B MTS Thawalib Putri Padang Panjang untuk menyelidiki keterpakaiannya.

Proses validasi dilakukan pada satu orang ahli rancangan/konstruk dan satu orang ahli/pakar isi bahasa Arab integratif. Rancangan perangkat pembelajaran direvisi menurut komentar dan saran dari ahli rancangan dan ahli isi. Rancangan tersebut menjadi prototipe awal.

\section{Efektifitas Bahan Ajar Bahasa Arab Terpadu Berbasis Tema}

Tahap assesmen adalah untuk melihat efektifitas dari bahan ajar bahasa Arab terpadu. Efektifitas yang diamati adalah pelaksanaan proses pembelajaan dengan bahan ajar, kesan siswa, dan hasil belajar yang dilihat dari hasil bahan ajar bahasa Arab. Tahap melihat efektifitas dilakukan bersamaan dengan melihat praktikalitas penggunaan bahan ajar yang dikembangkan. Untuk melihat efektifitas bahan ajar terhadap aktivitas belajar dan motivasi belajar siswa dilakukan dengan mengisi lembar cheklis. Wawancara juga dilakukan untuk melihat praktikalitas dan efektifitas penggunaan bahan ajar.

Sehubungan dengan hasil belajar dilihat dari hasil uji coba pada lima orang siswa MTs Thawalib Putra sebagai prototipe I. Uji coba tersebut bertujuan untuk melihat praktikalitas (keterpakaian) bahan ajar bahasa Arab terpadu oleh siswa kelas VII. Ujicoba bahan ajar dilakukan pada kelompok terbatas yaitu pada siswa kelas VII MTS Thawalib Putra yang akan mengikuti bahan ajar berjumlah 5 orang dengan berbagai ragam tingkat kemampuan. Pemilihan subjek uji coba berdasarkan hasil analisis dokumen yaitu latar belakang siswa, nilai beberapa mata pelajaran bahasa Arab dan wawancara dengan beberapa orang guru bahasa Arab.

Sebelum uji coba dilaksanakan, peneliti berdiskusi dengan guru pengampu mata pelajaran bahasa Arab dan salah seorang guru lainnya mempersiapkan proses pembelajaran. Persiapan yang dilakukan adalah memahami konsep pembelajaran bahan ajar dan menentukan tugas masingmasing. Uji coba ini direncanakan untuk 6 kali tatap muka dengan waktu masingmasingnya satu jam belajar (45 menit). Namun dalam pelaksanaannya hanya terpakai dua kali tatap muka, karena keterbatasan waktu.

Untuk melihat praktikalitas perangkat pembelajaran yang digunakan dalam proses pembelajaran diperoleh melalui pengamatan (observasi) terhadap proses pembelajaran, kesan dari guru dan siswa selama proses pembelajaran, dan hasil uji coba bahan ajar.

1. Observasi pada pelaksanaan proses pembelajaran bahan ajar

Untuk melihat apakah penggunaan bahan ajar dalam proses pembelajaran dapat dikatakan praktis, maka dilakukan pengamatan oleh observer. Pengamatan dilakukan terhadap kemudahan guru dan siswa dalam menggunakan dan memahami bahan ajar. Hasil pengamatan yang dituangkan observer dalam catatan lapangan/lembar observasi terbuka diperoleh keterangan bahwa penggunaan bahan ajar bahasa Arab terpadu dapat dikatakan praktis. Selama proses pembelajaran dengan tiga kali tatap muka terlihat tidak terdapat banyak permasalahan. Bagi guru mudah menggunakan bahan ajar bahasa Arab terpadu. Untuk siswa terlihat sedikit yang bertanya mengenai isi dan tampilan/format penulisan bahan ajar. Siswa yang menemukan kesulitan dalam menggunakan dan memahami bahan ajar merupakan siswa dengan tingkat kemampuan rendah. Rata-rata kesulitan yang mereka peroleh pada memahami contoh dan soal latihan yang diberikan. Namun, rata-rata siswa dapat menyelesaikan satu unit materi pada bahan ajar untuk setiap kali tatap muka.

Setelah mengamati pelaksanaan proses penggunaan bahan ajar, hasil 
observasi, kesan umum siswa setelah mengikuti pembelajaran, wawancara terhadap guru dan siswa, maka dapat disimpulkan oleh observer mengenai praktikalitas portotipe pembelajaran. Untuk penilaian observer terhadap praktikalitas pembelajaran dapat ditunjukkan pada tabel berikut:

\begin{tabular}{|l|c|c|c|c|}
\hline \multirow{2}{*}{ Objek yang Dinilai } & \multicolumn{2}{|c|}{ Pengamat } & \multirow{2}{*}{ Jml } & $\%$ \\
\cline { 2 - 5 } & 1 & 2 & & \\
\hline $\begin{array}{l}\text { Bahan ajar bahasa Arab terpadu mudah digunakan } \\
\text { dan dipahami }\end{array}$ & 4 & 4 & 8 & 80 \\
\hline $\begin{array}{l}\text { Bahan ajar bahasa Arab Terpadu sangat berguna } \\
\text { meningkatkan proses pembelajaran }\end{array}$ & 5 & 4 & 9 & 90 \\
\hline $\begin{array}{l}\text { Penggunaan bahan ajar tepat sasaran/sesuai } \\
\text { dengan prinsip pembelajaran bahan ajar }\end{array}$ & 4 & 4 & 8 & 80 \\
\hline $\begin{array}{l}\text { Waktu yang dirancang memperlajari bahan ajar } \\
\text { memadai }\end{array}$ & 3 & 3 & 6 & 60 \\
\hline $\begin{array}{l}\text { Siswa menyenangi belajar dengan bahan ajar } \\
\text { terlihat dari aktivitas siswa }\end{array}$ & 4 & 4 & 8 & 80 \\
\hline $\begin{array}{l}\text { Siswa menyenangi belajar dengan bahan ajar } \\
\text { terlihat dari motivasi siswa }\end{array}$ & 4 & 4 & 8 & 80 \\
\hline Jumlah & 25 & 24 & 47 & 78.33 \\
\hline
\end{tabular}

Persentase hasil penilaian hasil observer menunjukkan bahwa penilaian berkisar antara 60\%-90\%. Berdasarkan kriteria yang terdapat pada tabel di atas menunjukkan bahwa perangkat pembelajaran bahasa Arab terpadu sangat berguna dalam proses pembelajaran. Secara umum penilai berpendapat bahwa penggunaan perangkat pembelajaran bahasa Arab Terpadu secara keseluruhan sangat praktis. Namun bahan ajar tersebut masih mempunyai sedikit revisi setelah dilaksanakan uji coba terbatas.

2. Kesan siswa terhadap penggunaan bahan ajar

Setelah siswa menyelesaikan proses pembelajaran selama tiga kali tatap muka, peneliti memberikan angket kepada siswa mengenai kesan siswa selama mengikuti proses pembelajaran dengan menggunakan bahan ajar bahasa Arab terpadu. Setelah kuisioner diisi siswa terkumpul, maka peneliti menganalisis angket tersebut berdasarkan persentase dari jawaban yang dipilih masing-masing siswa. Data dan analisis angket tentang kesan siswa selama proses pembelajaran menunjukkan bahwa lebih dari $85,71 \%$ dari siswa memberikan kesan yang baik selama mengikuti proses pembelajaran dengan menggunakan bahan ajar bahasa Arab Terpadu. Selain itu lebih dari $71,42 \%$ siswa menyatakan bahwa bahan ajar bahasa Arab terpadu mudah digunakan. Namun pemahaman siswa terhadap soal-soal yang diberikan mendapatkan prosentase yang paling rendah, yaitu hanya 64,28\%. Kebanyakan siswa yang berkemampuan rendah sedikit mengalami kesulitan untuk belajar dengan menggunakan bahan ajar, mereka masih butuh bantuan dan waktu yang lebih untuk menyelesaikan bahan ajar.

Wawancara yang dilakukan kepada guru yaitu setelah pelaksanaan proses pembelajaran. Tujuan wawancara untuk mengetahui sejauh mana pelaksanaan proses pembelajaran dengan menggunakan bahan ajar terpadu terlaksana. Hasil wawancara dari guru menyatakan bahwa perangkat pembelajaran bahasa Arab Terpadu yang digunakan sudah praktis. Hanya pengaturan waktu yang belum bisa dipastikan karena tergantung pada kecepatan dan kemampuan siswa. Menurut pendapat guru, jika kemampuan siswa yang diajarkan mempunyai kemampuan yang baik tentu pembelajaran dengan bahan ajar akan lebih optimal hasilnya.

3. Hasil bahan ajar terpadu

Setelah dilakukan validasi, selanjutnya dilakukan tahap revisi bahan ajar pembelajaran bahasa Arab Terpadu berdasarkan saran dan komentar validator. Setelah itu dilakukan uji coba di kelas VIII Thawalib Putra dengan subjek penelitian berjumlah 5 orang. Proses pembelajaran mengacu pada Rencana Pelaksanaan Pembelajaran (RPP) yang telah dirancang yaitu sebanyak tiga kali pertemuan. Berikut ini hasil belajar kognitif, afektif dan psikomotor siswa setelah dilakukan ujicoba kelas riil (nyata) sebanyak tiga 
kali pertemuan.

Hasil belajar kognitif siswa dilihat dari hasil tes sikap skala Likert. Tes kognitif ini diberikan setelah kegiatan pembelajaran selesai dilaksanakan dengan hasil skor tes kognitf berikut:

\begin{tabular}{|l|l|l|l|l|l|l|}
\hline No & Nama & $\begin{array}{l}\text { Workshee } \\
t \text { Unit 1 }\end{array}$ & $\begin{array}{l}\text { Workshee } \\
t \text { Unit 2 }\end{array}$ & $\begin{array}{l}\text { Workshee } \\
t \text { Unit 3 }\end{array}$ & $\begin{array}{l}\text { Evaluati } \\
\text { on sheet }\end{array}$ & Rerata \\
\hline 1 & $\mathrm{A}$ & 79 & 82 & 81 & 85 & 81.75 \\
\hline 2 & $\mathrm{~B}$ & 80 & 82 & 83 & 87 & 83.00 \\
\hline 3 & $\mathrm{C}$ & 83 & 80 & 83 & 82 & 82.00 \\
\hline 4 & $\mathrm{D}$ & 82 & 83 & 84 & 85 & 83,50 \\
\hline 5 & $\mathrm{E}$ & 89 & 90 & 85 & 90 & 88,25 \\
\hline Jumlah & & & & & 418,50 \\
\hline Rerata & & & & & 83,70 \\
\hline
\end{tabular}

Berdasarkan data di atas, persentase siswa yang mengalami ketuntasan belajar sebesar 100\% dengan rata-rata nilai kelas yaitu 83,70. Kriteria ketuntasan minimal siswa yang diterapkan di Thawalib Putra adalah $\geq 72$. Bila nilai worksheet yang diperoleh siswa $<72$, maka siswa mengulang kembali materi dalam worksheet dengan menggunakan bantuan materi dalam modul dan sumber pustaka lain yang mendukung. Bila nilai worksheet siswa $\geq 72$, siswa dapat mengerjakan worksheet selanjutnya. Pada akhir pembelajaran, apabila siswa sudah mengerjakan semua worksheet dan tuntas secara keseluruhan maka siswa diperbolehkan meminta evaluation sheet kepada guru.

Hasil belajar afektif siswa dilihat dari hasil tes sikap skala Likert. Tes sikap ini diberikan setelah kegiatan pembelajaran selesai dilaksanakan. Berdasarkan data hasil skor tes sikap, diketahui bahwa siswa menunjukkan kriteria sikap baik dengan ratarata sebesar 74,28 dengan kriteria A. sebagaimana dalam tabel berikut ini:

\begin{tabular}{|c|c|c|c|}
\hline No. & Nama & $\begin{array}{ll}\text { Total } & \text { Skor } \\
\text { Afektif } & \end{array}$ & Kriteria \\
\hline 1. & A & 84.78 & $A$ \\
\hline 2. & B & 88.10 & A \\
\hline 3. & C & 80.50 & A \\
\hline 4. & D & 81.58 & $A$ \\
\hline 5. & E & 87.80 & $\mathrm{~A}$ \\
\hline \multicolumn{2}{|c|}{ Rata-rata } & 84,55 & $\mathrm{~A}$ \\
\hline
\end{tabular}

Hasil data afektif siswa yang diperoleh berdasarkan tabel di atas menunjukkan bahwa pembelajaran menggunakan modul pembelajaran bahasa Arab Terpadu dapat meningkatkan sikap/minat siswa. Rata-rata nilai sikap siswa yaitu sebesar 84,55\%. Setelah dilakukan ujicoba, komentar dan saran siswa terhadap modul pembelajaran bahasa Arab Terpadu ini yaitu gambar-gambar yang yang terpadu dengan dengan bahan ajar sangat membantu dan memudahkan siswa pada bahasa Arab yang dipelajari.

Nilai psikomotor siswa diperoleh dari kegiatan observasi pada pertemuan pertama. Rata-rata siswa memperoleh nilai psikomotor sebesar 88.

\section{Pembahasan}

Penyusunan awal bahan ajar pembelajaran terpadu ini dikembangkan berdasarkan karakteristik siswa sebagai sampel penelitian yang notabene terdiri dari 20 orang $(44,44 \%)$ dari kelompok kemampuan rendah, 4 orang $(8,88 \%)$ dari kelompok kemampuan sedang dan 4 orang $(8,88 \%)$ dari kelompok berkemampuan tinggi. Variasi karakteristik siswa disusun materi bahan ajar bahasa Arab yang disesuaikan dengan karakteristik mereka dengan tema berikut:

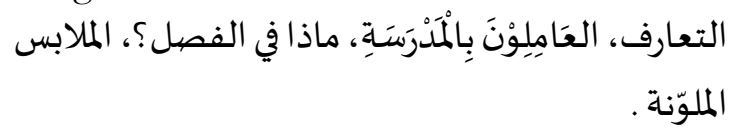

Mengenali karakteristik anak didik merupakan langkah awal yang sangat penting untuk memudahkan penulis merumuskan bentuk bahan ajar. Dengan mengenali karakteristik anak didik, penulis dapat merencanakan sekenario pembelajaran yang tepat sesuai dengan kebutuhan anak. Dengan demikian proses penggunan bahan ajar dalam pembelajaran menjadi lebih efektif dan efisien. Efektif artinya dapat menjadi tujuan pembelajaran dengan baik, sedangkan efiesien artinya tujuan pembelajaran dicapai dalam waktu yang relatif singkat. Pemilihan dan penentuan bahan ajar dimaksudkan untuk memenuhi salah satu kriteria bahwa bahan ajar harus menarik, dapat membantu siswa untuk mencapai kompetensi. Sehingga bahan ajar dibuat sesuai dengan kebutuhan dan kecocokan 
dengan KD yang akan diraih oleh peserta didik. Jenis dan bentuk bahan ajar ditetapkan atas dasar analisis kurikulum dan analisis sumber bahan sebelumnya.

Perancangan

perangkat pembelajaran yang telah dikonsultasikan mendapatkan revisi yang tidak terlalu prinsip antara lain tentang penyeragaman gambar bahan ajar dan penekanan topik-topik yang krusial dalam bahasa Arab yang aplikatif. Hal penting yang perlu diperhatikan supaya terujud keseimbangan materi terpadu ini. Dari analisis data mengenai validitas isi dan validitas rancangan/rancangan yang telah dinilai oleh validator menunjukkan bahwa validitas perangkat pembelajaran bahan ajar bahasa Arab terpadu pada siswa kelas VII MTs Thawalib yang dikembangkan termasuk dalam kriteria valid, ini menunjukkan bahwa perangkat pembelajaran yang dikembangkan dapat mengukur apa yang seharusnya diukur dengan tepat, dan terdapat keterkaitan antara bahan ajar satu dengan bahan ajar/ materi lainnya.

Dari pendapat yang diberikan validator tentang perangkat pembelajaran bahan ajar bahasa Arab Terpadu pada siswa MTs Thawalib Putra dikatakan valid dapat dirinci sebagai berikut: Komentar para validator terhadap bahan ajar bahasa Arab terpadu adalah: 1) perancangan bahan ajar sudah sesuai dengan prinsip pengembangan bahan ajar bahan ajar, menarik dan berdaya guna dan 2) bahan ajar yang dikembangkan sudah dapat digunakan untuk pelaksanaan uji coba lapangan/ terbatas jika bahan ajar tersebut telah direvisi.

Perangkat pembelajaran bahan ajar bahasa Arab Terpadu di kelas VII MTs Thawalib Putra dikategorikan valid berdasarkan hasil validasi berikut;

Pertama, penyusunan bahan ajar bahasa Arab Terpadu disesuaikan dengan format penulisan bahan ajar. Format penulisan ini dilengkapi dengan penulisan kerangka isi materi. Upaya tersebut dapat memudahkan siswa dalam mendapatkan gambaran/informasi mengenai materi yang dipelajari. Hal ini sesuai dengan pendapat Ausubel (1968) bahwa kerangka isi materi bertindak sebagai unit konseptual sebagai informasi struktur kognitif dalam belajar.

Kedua, penulisan petunjuk pembelajaran tepat dan dapat memberikan kemudahan kepada siswa dalam mempelajari bahan ajar. Dick dan Carey (1990) membuktikan dalam penelitiannya tentang penulisan petunjuk pembelajaran dalam buku ajar bahwa penulisan petunjuk juga memberikan arahan kegiatan pembelajaran yang harus dilakukan dalam proses pembelajaran, dan menurut Joni (1981) petunjuk penggunaan buku ajar berupa rasional dan gambaran umum tentang penggunaan buku ajar.

Ketiga, format penulisan bahan ajar untuk jenis dan ukuran huruf sudah tepat, dan menarik yaitu Sakkal Majalla dengan font 16 untuk Arabi. Format penulisan dapat memudahkan siswa, serta sesuai dengan aturan dan gaya penulisan karya ilmiah.

Keempat, konsep materi yang dikembangkan dalam bahan ajar sudah tepat, sesuai dengan kurikulum bahasa Arab 2014. Penyusunan dan pemilihan materi sesuai dengan prinsip yang mengarah memudahkan siswa dalam mempelajarinya. Prinsip tersebut seperti yang dijelaskan oleh Winkel(1991;195) bahwa (1) materi pelajaran harus relevan terhadap tujuan pembelajaran yang hendak dicapai, (2) materi pelajaran harus sesuai dengan taraf kesulitannya dengan kemampuansiswa untuk menerima dan mengolah materi tersebut, (3) materi pelajaran harus dapat menunjang motivasi siswa, (4) materi pembelajaran harus dapat membantu siswa untuk melibatkan dirinya secara aktif, baik dengan berpikir sendiri maupun dengan melakukan berbagai kegiatan, (5) materi pelajaran harus sesuai dengan prosedur pembelajaran, dan (6) materi pembelajaran harus sesuai dengan media pembelajaran yang tersedia.

Kelima, contoh-contoh materi diambilkan dari kata-kata (mufradat) yang dekat dengan siswa. Pemilihan ini 
disesuaikan dengan prinsip pengembangan dalam pengajaran kosakata, di antaranya kefamiliaran (al-ulfab). Maksudnya, kata yang lebih familiar (sering didengar dan digunakan) harus diprioritaskan pembelajarannya darbaasa Arabda kata yang jarang dan langka, meskipun mempunyai kesamaan arti (Rusdîy, 1989:196)

Setelah bahan ajar didiskusikan pada para pakar, dan berdasarkan hasil revisi maka selanjutnya bahan ajar diujicobakan pada kelompok siswa. Uji coba kelompok ini terbagi dua, uji coba kelompok kecil dan dilanjutkan dengan uji coba lapangan dalam jumlah yang lebih besar dari sebelumnya.

Uji coba kelompok kecil dilakukan pada enam orang siswa yang berbeda tingkat kemampuannya. Hasil dari uji coba pada kelompok kecil ini tidak terlalu banyak mendapatkan revisi. Revisi yang diberikan oleh siswa cenderung pada pembuatan padanan bahasa Arab dalam bahasa Indonesia .

Setelah bahan ajar diuji cobakan pada kelompok kecil, selanjutnya bahan ajar direvisi. Berdasarkan hasil revisi yang tidak banyak dan hampir sama dengan uji coba kelompok kecil. Untuk siswa yang tergolong kelompok pintar memberikan revisi yang sangat bagus yaitu perbaikan pada sistematika materi yang dibutuhkan pada buku wajib. Hasil uji coba dari pada kelompok kecil dan lapangan ini menjadi bentuk prototipe II.

Untuk membuktikan perangkat pembelajaran ini praktis berdasarkan hasil analisis data secara deskriptif. Pertama, berdasarkan hasil observasi/pengamatan dan kesan siswa serta hasil angket praktikalitas terhadap penggunaan perangkat pembelajaran selama proses pembelajaran secara umum dapat dinyatakan bahwa penggunaan bahan ajar bahasa Arab Terpadu tidak mendapatkan kendala yang berarti, dengan arti lain situasi berjalan dengan normal. Siswa merasa senang belajar dengan menggunakan bahan ajar, mudah dalam menggunakan bahan ajar. Hal ini sesuai dengan prinsip pembelajaran dengan bahan ajar yaitu pembelajaran yang memberikan pengakuan atas perbedaan-perbedaan individual. Belajar dengan menggunakan bahan ajar dapat memberikan kesempatan kepada siswa untuk menyesuaikan dengan kemampuan dan kecepatan masing-masing. Guru semakin banyak memiliki kesempatan untuk menolong siswa secara individual dalam proses pembelajaran. Namun demikian proses pembelajaran tetap berpusat kepada siswa. Guru hanya berperan sebagai fasilitator. Siswa memperoleh informasi berulang-ulang tentang kemajuan belajar yang telah dicapainya.

Kedua, berdasarkan hasil wawancara dengan guru dan siswa terhadap penggunaan bahan ajar secara umum dapat dinyatakan bahwa: penggunaan bahan ajar praktis dan menarik, karena pembahasan materi disesuaikan dengan kebutuhan siswa yang notabene tidak memiliki kemampuan dasar bahasa Arab. Bahan ajar juga praktis dalam upaya menangulangi materi yang tertinggal dengan cara belajar mandiri oleh masingmasing siswa. Siswa merasakan proses pembelajaran lebih baik dari sebelumnya. Rata-rata mereka itu pada awalnya tidak mengenal istilah-istilah penting dalam bahasa Arab Terpadu dan penggunaannya. Dengan menggunakan bahan ajar ini siswa lebih enjoy dan senang belajar bahasa Arab.

\section{Penutup}

Berdasarkan hasil penelitian, dapat disimpulkan bahwa 1) pengembangan ini menghasilkan produk berupa materi bahasa Arab terpadu berbasis tema untuk membentuk keterampilan bahasa di kelas VII MTs Thawalib Padang Panjang, 2) Materi ajar bahasa Arab terpadu berbasis tema di kelas VII MTs Thawalib Padang Panjang dikategorikan valid berdasarkan hasil validasi berikut: penyusunan bahan ajar disesuaikan dengan format penulisan bahan ajar, penulisan petunjuk pembelajaran dapat memberikan kemudahan kepada siswa dalam mempelajari bahan ajar, format penulisan bahan ajar untuk jenis dan ukuran huruf 
sudah tepat, dan menarik, Penyusunan dan pemilihan materi sesuai dengan prinsip yang mengarah memudahkan siswa dalam mempelajarinya, dan contoh-contoh materi diambilkan dari kata-kata (mufradat) yang dekat dengan siswa, dan 3) Praktikalitas materi bahasa Arab terpadu yang berbasis tema yang dikembangkan efektif dalam membentuk keterampilan berbahasa siswa di kelas VII MTs Thawalib Padang Panjang.

\section{DAFTAR RUJUKAN}

Ainin, Moh. 2010. Metode Penelitian Bahasa Arab. Surabaya: Hilal Pustaka.

Astuti, Widi. 2015. Model Pembelajaran Bahasa Arab Terpadu di MAPK MAN 1 Surakarta. Jurnal Komunikasi dan Pendidikan Islam, 4 (2).

Ja'far Al-Khalifah, Hasan. 2004. Fusbul Fi Tadris Al-Lughah Al'Arabiyyah. Riyadh: Maktabah Ar-Rusdy.

Makruf, Imam. 2016. Manajemen Integrasi Pembelajaran Bahasa Arab di Madrasah Berbasis Pondok Pesantren. Cendekia, 14 (2).

Salam, Yufridal Fitri Nur. 2011. Signifikan
Pendekatan All in One System pada Keterampilan Bahasa Arab. Cendikia, 9 (1).

Sirjan, Abdul Majid. 1981. Al-Manabij al Mu'ashirah. Kuwait: Maktabat al Falah

Sugiyono. 2011. Metode Penelitian Kuantitatif, Kualitatif dan $\mathrm{R}$ \& $D$. Bandung: Alfabeta

Supardi. 2018. Model Pembelajaran Bahasa Arab Terpadu di Perguruuan Tinggi Ke agamaan Islam Negeri. Lisania: Journal of Arabic Education and Literature, 2 (1).

Thu'aimah, Rusdîy Ahmad. 1989. Ta'lim alArabiyah lighairi an-Nathiqin biha Manabijubu wasalibubu. Rabât: ISESCO.

Winkel, WS. 1991. Psikologi Pengajaran. Jakarta: Gramedia.

Yunus, Mahmud. 1983. Metodik Khusus Bahasa Arab (Bahasa Al-Qur'an). Jakarta: Hidakarya Agung.

Zulhannam. 2014. Teknike Pembelajaran Bahasa Arab Interaktif. Jakarta: PT Raja Grafindo Persada. 